\title{
DAMPAK PEMBANGUNAN KAWASAN INDUSTRI DI KABUPATEN BEKASI TERHADAP ALIH FUNGSI LAHAN DAN MATA PENCAHARIAN PENDUDUK
}

\author{
Oleh : Djakaria M.Nur*)
}

\begin{abstract}
Abstrak
Wilayah kabupaten Bekasi yang letaknya berbatasan dengan Daerah Khusus Ibu Kota (DKI) Jakarta pada akhir akhir ini mengalami perkembangan pembangunan yang sangat pesat. Berdasarkan kebijakan pemerintah wilayah-wilayah yang berada di sekitar DKI Jakarta seperti Bakasi, Tanggerang, Cilegon dikembangkan sebagai wilayah pusat/ kawasan industri. Tidak kurang dari $5.000 \mathrm{Ha}$ di wilayah kabupaten Bekasi diperuntukan sebagai wilayah kawasan industri. Dengan dijadikan wilayah kawasan industri terebut berdampak terhadap alih fungsi lahan dan sektor usaha/matapencaharian penduduk di wilayah tersebut.
\end{abstract}

Kata kunci: kawasan industri, alih fungsi lahan, mata pencaharian.

\section{Pendahuluan}

Secara fisiografis wilayah kabupaten Bekasi merupakan wilayah yang berada pada zone Jakarta dengan topografinya yang datar. Sebagian besar keadaan tanahnya merupakan tanah alluvial yang subur untuk daerah pertanian. Oleh karena itu wilayah kabupaten Bekasi merupakan wilayah pertanian bersama dengan wilayah Kerawang, Subang, Indramayu dan Cirebon sebagai andalan Jawa Barat dalam produksi padi. Sebagai daerah pertanian wilayah kabupaten Bekasi selain ditunjang oleh kondisi iklim terutama cuirah hujan yang tinggi yaitu berkisar antara $2.000-2.500 \mathrm{~mm} /$ tahun juga sudah dilengkapi dengan saluran irigasi baik saluran primer, sekunder sampai tersier. Oleh karena itu sebagian besar penduduknya hidup dalam sektor pertanian.

*) Drs. Djakaria M. Nur, M.Si adalah dosen Jurusan Pendidikan Geografi FPIPS UPI. 
Pembangunan sektor industri bagi Indonesia merupakan hal yang harus dilakukan, mengingat jumlah angkatan kerja banyak, yang tidak mungkin dapat diatasi hanya pada sector pertanian. Dengan industri tenaga kerja akan banyak terserap baik secara langsung maupun tidak langsung. Dengan pembangunan industri dapat terbuka bidang -bidang usaha lainnya seperti berbagai kegiatan dalam sector jasa.

Tidak ada pembangunan yang tidak memerlukan lahan, setiap pembagunan lebih-lebih pembangunan fisik akan memerlukan lahan. DKI Jakarta sebagai Ibu Kota Negara sudah tidak memungkinkan lagi pembangunan industri, karena lahan terbuka di wilayah ini sudah sangat terbatas. Oleh karena itulah wilayah yang ada di sekitar Jakarta seperti Bekasi, Tanggerang, Cilegon di jadikan wilayah untuk pengembangan industri. Dengan industri yang dikembangkan di wilayah sekitar Jakarta, maka penduduk yang ingin masuk kota Jakarta dari berbagai pesolok daerah-daerah lain di Indonesia dapat tersalurkan pada daerah sekitar kota Jakarta tersebut. Urbanisasi untuk masuk ke kota Jakarta dapat berkurang.

Sehubungan dengan itu penelitian ini bertujuan untuk mengetahui lebih mendalam tentang pengaruh pembangun an kawasan industri terhadap alih fungsi lahan terutama lahan pertanian seta terhadap usaha/mata pencaharian penduduk kabupaten Bekasi itu sendiri.

\section{Metode Penelitian}

a. Ruang Lingkup Penelitian

Wilayah kajian dalam penelitian ini adalah wilayah administrasi kabupaten Bekasi dengan luas 127.388 hektar. Sedangkan ruang lingkup kajian meliputi analisis alih fungsi lahan dan perubahan berbagai sektor usaha/mata pencaharian penduduk serta korelasi perubahan alih fungsi lahan dengan berbagai sector usaha penduduk yang terjadi di wilayahpenelitian

b. Bahan Penelitian

Bahan yang digunakan dalam penelitian ini adalah data spasial dan data tabuler.

Data tersebut meloputi data fisik seperti ;

1) Pata Rupa Bumi skala 1:50.000 produksi BAKO SURTANAL tahun 1987 
2) Peta Penggunaan Tanah Wilayah Kabupaten Bekasi 1990 skala 1 : 50.000

3) Peta Penggunaan tanah Wilayah Kabupaten Bekasi 1999 skala 1 : 50.000

4) Pata Topografi Wilayah Kabupaten Bekasi skala 1 : 100.000

Data Sosial yang diperlukan meliputi ;

1) Jumlah penduduk Kabupaten Bekasi tahun 1990 - 1999

2) Jumlah dan kepadatan penduduk perkecamatan tahun 1990 1999

3) Jumlah penduduk berdasar kan sector usaha tahun 1990 - 1999.

c. Metode Analisis Data

Metode analisis datadilakukan dengan analisis spatial dan metode analisis statistic

1). Metode Analisis Spatial

Analisis spatial dilakukan untuk mengetahui perubahan luas alih fungsi lahan yang terjadi pada kurun waktu antara tahun 1990 - 1999 di wilayah Kabupaten Bekasi.

Untuk mengetahui persebaran dan penggunaan tanah tahun 1990 maupun tahun 1999 dengan menganalisis peta penggunaan tanah tahun-tahun tersebut. Analisis dan penyusunan data atribut dilakukan dengan mengguna kan software Arch Info sehingga tersusun format data dalam SIG (link spatial dengan tabuler). Peta alih fungsi penggunaan tanah 1900 - 1999 dihasilkan melaui proses overlay antara peta penggunaan tanah tahun 1900 dengan peta pengguna an tanah tahun 1999.

Teknik overlay adalah cara pengtumpangsusunan dari dua peta tematik. Peta penggunaan tanah baik tahun 1900 maupun tahun 1999 dilakukan dengan jalan mendijitasi peta-peta tersebut yang bersekala $1: 50.000$.

Pengerjaan pengolahan data menggunakan software Arch Info versi 3.5 dan Arch View versi 3.1.

2). Metode Analisis Statistik

Dari analisis spatial didapat data tabuler berupa data penggunaan tanah tahun1900 dqn tahun 1999, serta luas perubahan/ alih fungsi lahan di wilayah kabupatejn Bekasi. Untuk data tabuler lainnya seperti data jumlah dan pertumbuhan pendu duk, kepadatan 
penduduk, tingkat pendidikan, jumlah penduduk berbagai sektor usaha yang merupakan data sekunder diperoleh dari berbagai lembaga pemerintahan maupun swasta.

Untuk mengetahui ada tidak adanya hubungan serta besarnya tingkat hubungan dengan meng gunakan statistik korelasi dua variable ( Variabel $\mathrm{X}$ dan $\mathrm{Y}$ ). Variabel tanah $(\mathrm{X})$ yang dibagi menjadi empat sub variabel yaitu tanah sawah, tanah tanah terbangun, tanah lering dan tanah untuk kepentingan lainnya. Sedangkan variable sektor usaha penduduk (Y) yang dibagi menjadi lima sub variable yaitu pertanian, industri, perdagangan, jasa dan lainnya.

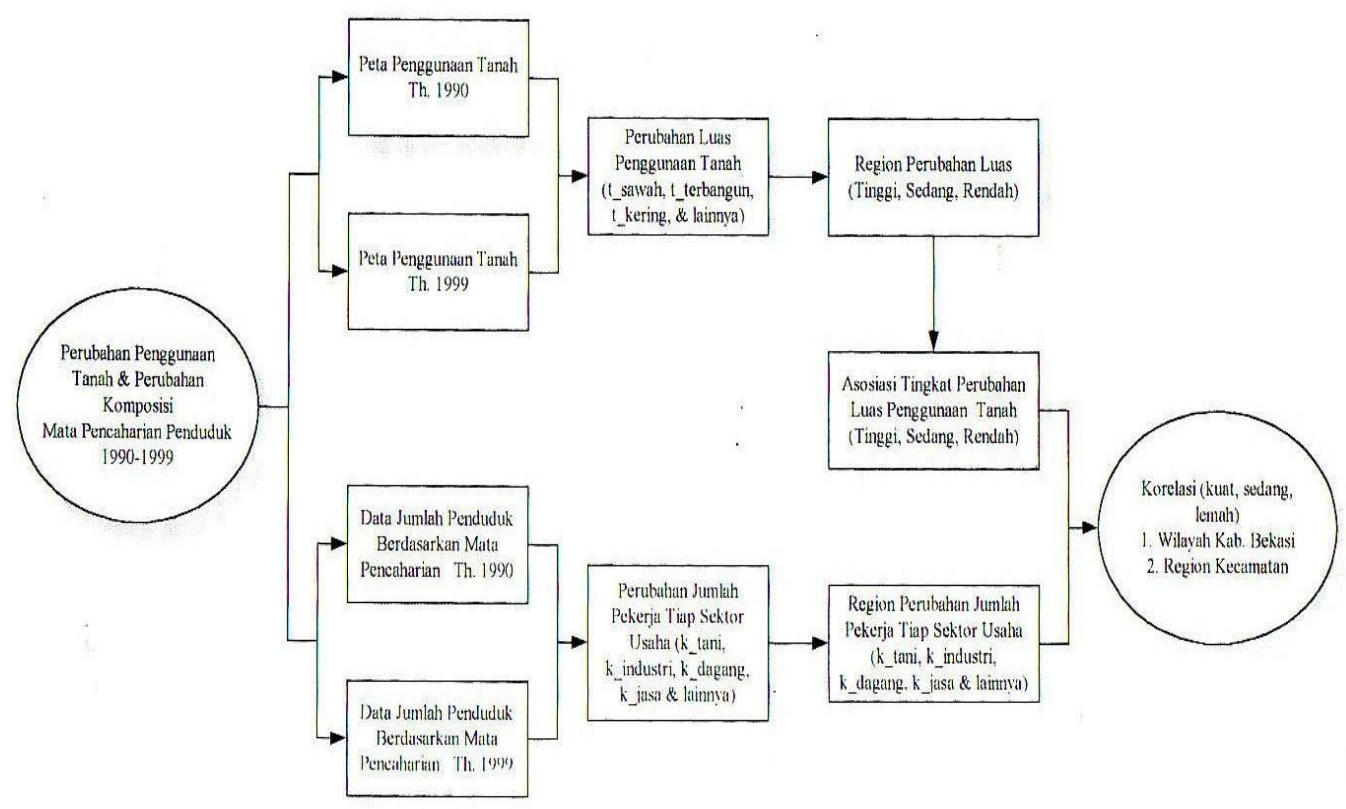

Gambar : Alur Analisis Data

\section{Hasil dan Pembahasan}

Dalam penelitian ini yang menjadi variabel penelitiannya adalah alih fungsi/perubahan penggunaan lahan terutama lahan sawah, perubahan komposisi sektor usaha/matapencaharian penduduk dan korelasi alih fungsi dengan perubahan komposisi sektor usaha/mata penderitaan penduduk. 


\section{a. Alih Fungsi Lahan}

Penggunaan lahan dalam penelitian ini didasarkan pada penggunaan lahan yang penulis analisis dari peta pengguna an lahan kabupaten Bekasi pada tahun 1990 dan 1999. Dari analisis peta tersebut penggunaan lahan di kabupaten Bekasi terdiri dari lahan sawah, lahan kering, lahan terbangun dan lahan pengunaan lainnya baik persebaran penggunaan, luas serta perubahan/alih fungsi lahan. Dari analisis spasial tersebut maka diperoleh data sebagai betrikut :

(1) Luas wilayah kabupaten Bekasi 127.388 hektar, sampai tahun 1900 di wilayah ini terdiri dari 65.612 hektar $(51,51 \%)$ merupakan tanah sawah, 19,884 hektar $(15,61 \%)$ lahan terbangun, 18.505 hektar $(14,53 \%)$ lahan kering, 23.387 hektar (18,16 \%) lahan untuk keperluan lainnya (perkebunan, hutan, empang, rawa dan sebagainya).

(2) Sedangkan pada tahun 1999 penggunaan lahannya sebagai berikut; 56.227 hektar $(44,14 \%)$ merupakan tanah sawah, 31.426 hektar $(24,67 \%)$ lahan terbangun, 10.751 hektar $(8,44 \%)$ lahan kering dan 28.984 hektar $(22,75 \%)$ penggunaan lahan lainnya.

Berdasarkan analisis hasil overlay peta penggunaan lahan tahun 1900 dengan 1999 terjadi alih fungsi/ perubah an penggunaan lahan seperti terjadi penurunan jumlah luas lahan sawah seluas 9.385 hektar dan penurunan jumlah luas lahan kering (tegalan, kebun) 7.754 hektar. Sedangkan luas lahan terbangun meningkat 11.542 hektar dan penggunaan lahan untuk keperluan lainnya mengalami peningkat an 5.595 hektar.

Berkurangnya luas lahan sawah seluas 9.385 hektar beralih fungsi menjadi ;

(1) lahan terbangun 8.630 hektar $(57,56 \%)$.

(2) lahan kering 4.854 hektar $(32,38 \%)$

(3) lahan untuk penggunaan lainnya 1.509 hektar $(10,06 \%)$.

Sedangkan berkurangnya luas lahan kering karena beralih fungsinya menjadi:

(1) lahan terbangun 7.850 hektar $(77,29 \%)$

(2) lahan sawah 2.149 hektar $(21,16 \%)$.

(3) lahan untuk keperluan lainnya 157 hektar (1,55\%).

Alih fungsi lahan terutama lahan sawah banyak tejadi pada wilayah yang dijadikan daerah kawasan industri yaitu di kecamatan Tambun, Cibitung, Cikarang, Lemahabang dan Serang Lokasinya disepanjang 
jalur jalan Tol yang menghubungkan kota Jakarta dibagian Barat dengan kota-kota lainnya dibagian Timur.

\section{b. Perubahan Komposisi Sektor Usaha/Matapencaharian Penduduk}

Sampai tahun 1900 penduduk usia kerja di kabupaten Bekasi yang bekerja pada sektor pertanian 309.731 orang $(60,9 \%)$, pedagang 61.807 orang $(12,15 \%)$, sector jasa 16.139 orang $(3,17 \%)$, sektor industri 13.462 orang $(2,65 \%)$ dan sebagai penganggur 107.406 orang $(21,12 \%)$. Sedangkan sepuluh tahun kemudia yaitu pada tahun 1999 pada sector pertanian mengalami penurunan menjadi 152.807 orang $(21,34 \%)$, pada sector industri mengalami perningkatan yang cukup besar menjadi 175.493 orang $(24,51 \%)$. Begitu juga dalam sector sector lainnya seperti perdagangan meningkat menjadi 118.064 orang $(16,49 \%)$, sector jasa meningkat memnjadi 117.945 orang $(16,47 \%)$.

Dari data tersebut manpak terjadi adanya pergeseran sektor usaha/mata pencaharian penduduk di wilayah kabupaten Bekasi. Sektor pertanian mengalami penurunan, sedangkan sektor-sektor lainnya mengalami peningkatan.

Dalam kurun waktu selama sepuluh tahun (1990-1999) terjadi penurunan jumlah penduduk yang bekerja pada sektor pertanian sebanyak 156.924 orang $(50,66 \%)$ dari jumlah penduduk yang bekerja pada sektor pertanian tersebut. Penurunan jumlah penduduk yang bekerja pada sektor pertanian sangat nampak sekali yaitu 91.310 orang $(58,19 \%)$ terjadi pada kecamatan-kecamatan dimana kawasan industri itu berada. Sisanya sekitar 65.614 orang $(42,80 \%)$ tersebar pada kecamatankecamatan lain yang ada di kabupaten Bekasi.

\section{c. Korelasi Alih Fungsi Lahan Dengan Perubahan Komposisi Sektor Usaha/ matapencaharian Penduduk}

Dari analisis tingkat assosiasi alih fungsi lahan dengan perubahan jumlah penduduk yang bekerja pada berbagai sektor usaha menggambarkan bahwa makin tinggi tingkat assosiasi perubahan luas penggunaan lahan berassosiasi kuat terhadap penurunan jumpah penduduk yang bekerja sebagai petani. Begitu juga kebalikannya, makin kecil tingkat assosiasi perubahan lahan berassosiasi kuat terhadap penurunan jumlah penduduk yang bekerja pada sektor pertanian. Kecamatan-kecamatan dengan tingkat assosiasi tinggi berada pada 
kecamatan-kecamatan yang merupakan derah kawasan industri seperti kecamatan Tambun, Cibitung, Cikarang, Lemahabang dan Serang.

Dari hasil analisis korelasi diperoleh dari data perubahan/alih fungsi lahan dengan perubahan jumlah pekerja pada berbagai sektor usaha penduduk diperoleh hasil sebagai berikut :

a. Perubahan penggunaan lahan sawah berdampak negatif terhadap perubah an jumlah penduduk yang bekerja pada sector industri $(\mathrm{r}=-$ $0,39)$, perdagangan $(\mathrm{r}=-0,13)$, jasa $(\mathrm{r}=-0,24)$ dan pengangguran $(\mathrm{r}$ $=-0,61)$, namun berkorelasi positif terhadap perubahan jumlah penduduk yang berusaha dalam sector pertanian $(\mathrm{r}=0,54)$. Ini menunjukkan bahwa makin berkurang luas lahan sawah yang terjadi di kabupaten Bekasi menga kibatkan bertambahnya jumlah penduduk yang bekerja pada sector industri, perdagangan dan jasa dan juga penduduk pengangguran.

b. Perubahan luas tanah terbangun berkorelasi negatif terhadap jumlah pekerja pada sector pertanian dan berkorelasi positif terhadap jumlah pekerja pada sector lain di luar sector pertanian. Perubahan positif yang dominant terjadi pada jumlah pekerja sector industri $(\mathrm{r}=0.46)$. Jumlah pekerja pada sector perdagangan dan sector jasa tidak terlalu besar $(r=0,32$ dan $r=26)$.

\section{Penutup}

Dengan dijadikannya wilayah kabupaen Bekasi sebagai kawasan industri mengakibatkan :

a. Terjadinya alih fungsi lahan sawah 9.385 hektar selama kurun waktu sepuluh tahun terakhir ini. Sebalik nya lahan terbangun termasuk lahan industri meningkat sebanyak 11.542 hektar.

b. Terjadi pergeseran sektor usaha/mata pencaharian penduduk dari sektor pertanian ke sektor industri, perdagangan dan jasa. .

c. Terdapat korelasi antara alih fungsi lahan dengan pergeseran sektor usaha/matapencaharian penduduk. Berkurangnya luas lahan sawah berkorelasi positif terhadap jumlah penduduk yang bekerja dalam sektor pertanian dan berkorelasi negatif terhadap jumlah pekerja dalam sektor industri, perdagangan maupun jasa. 


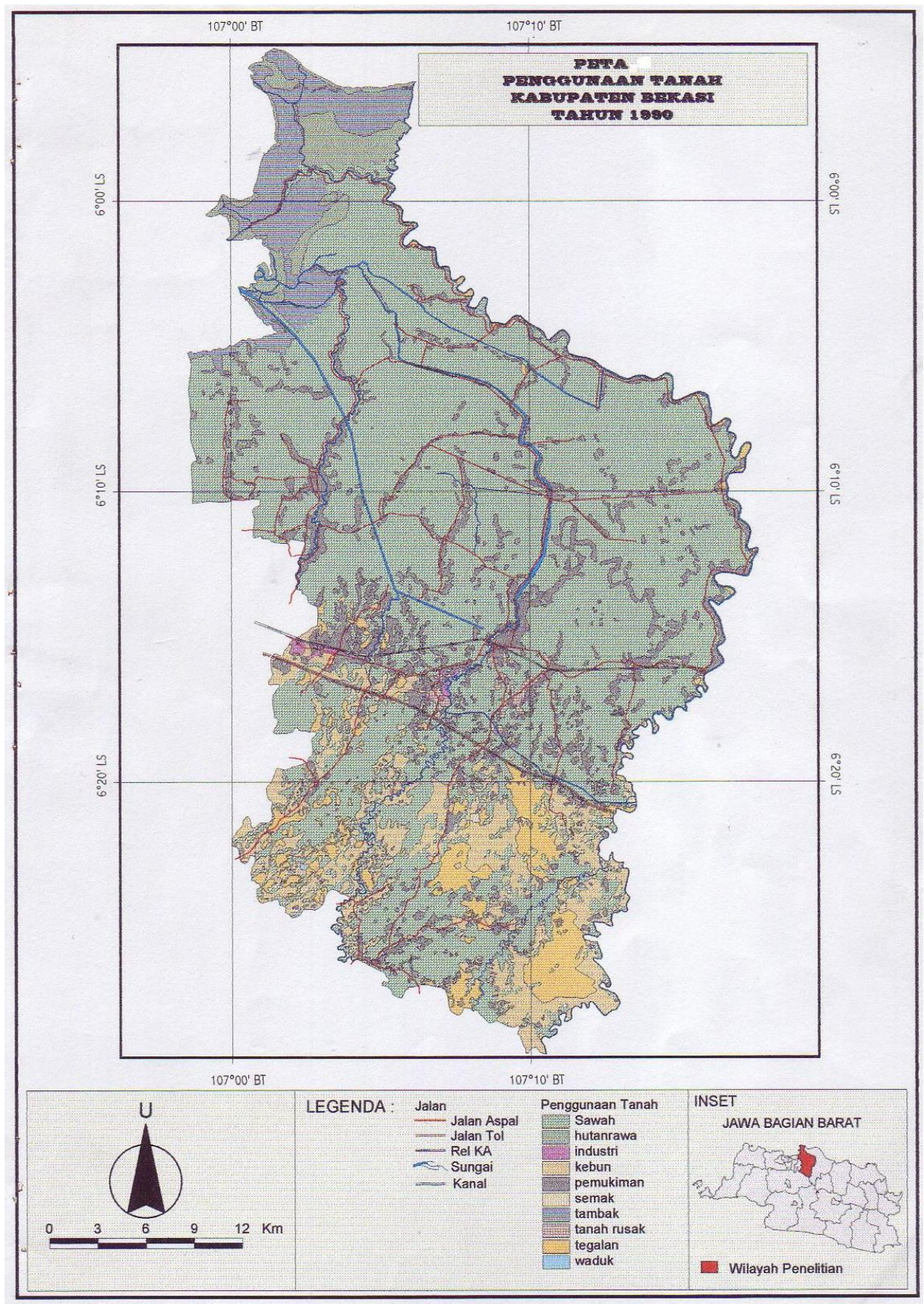




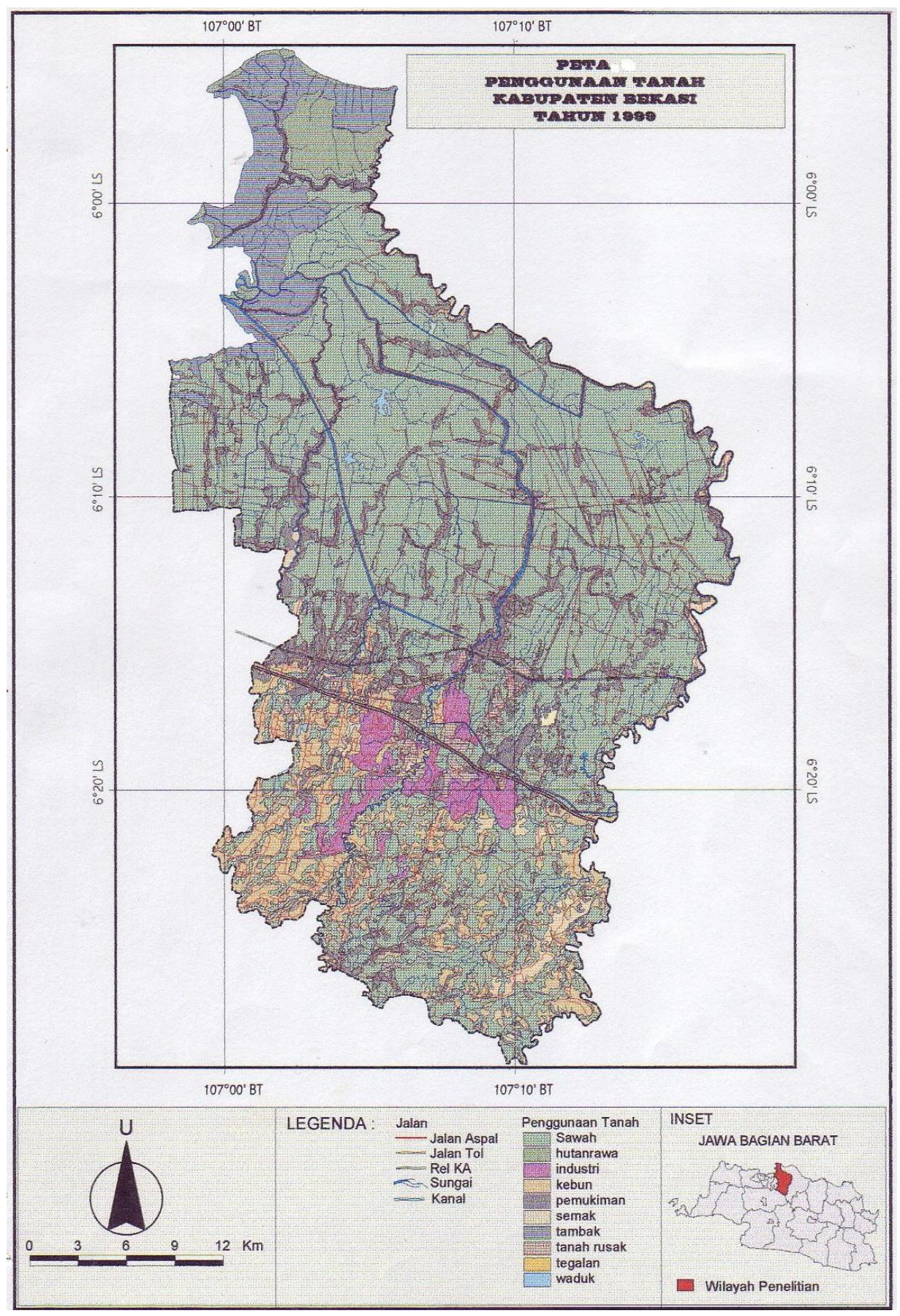




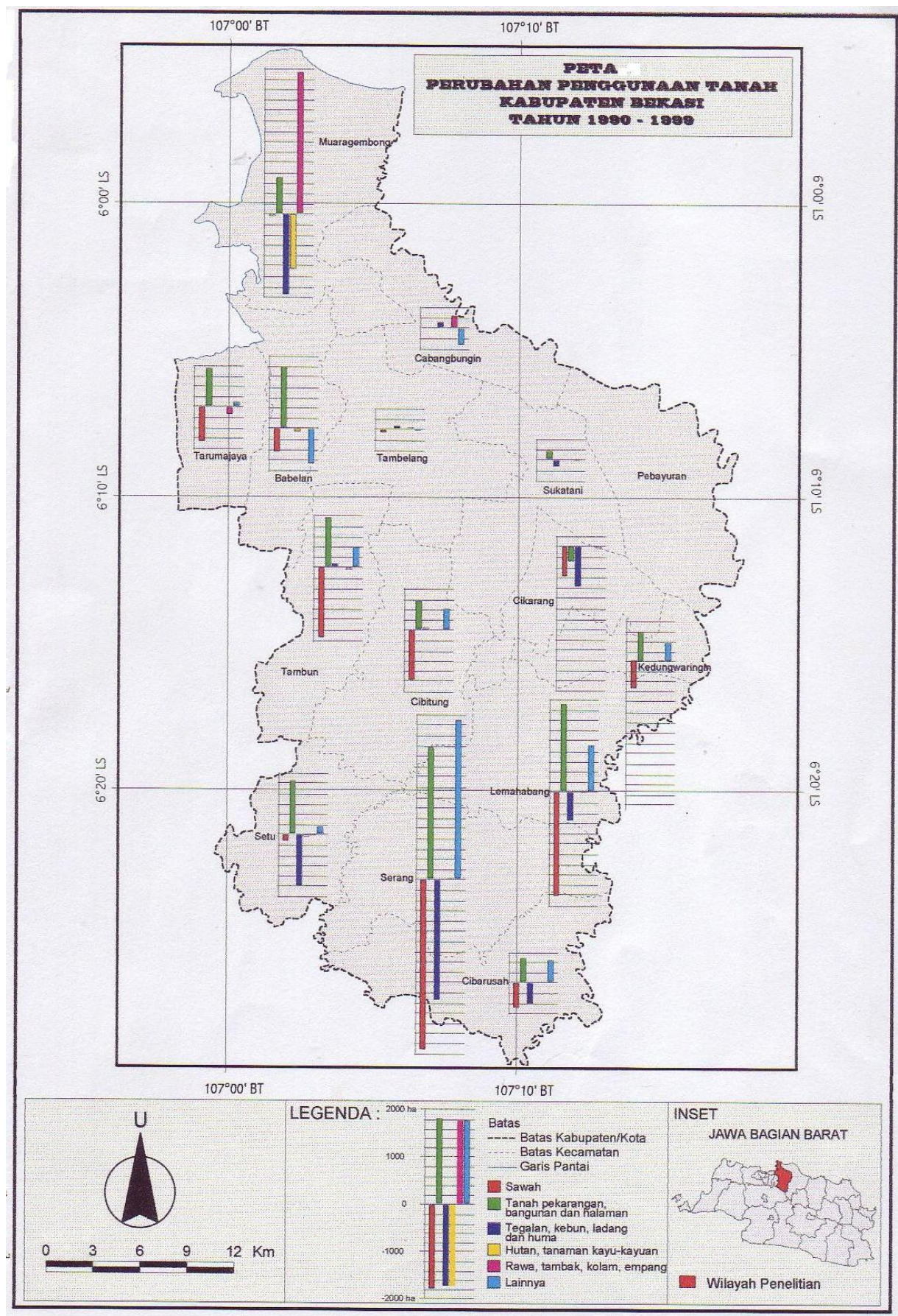




\section{Daftar Pustaka}

Budiharjo, E. 1995. Pendekatan Sistem Dalam Tata Ruang Pembangunan Daerah Untuk Meningkatkan Ketahanan Nasional. Yogyakarta: Gajah Mada University Press.

Glasson, J. 1977. Pengantar Perencana an Regional. Jakarta: Lembaga Penerbit FE UI..

Koestoer, R.H. 1977. Perspektif Lingkungan Desa-Kota Teori Dan Kasus. Jakarta: Universitas Indonesia Press.

Raharjo,S. 1999. Geografi dan Penerapannya Dalam pembangunan Wilayah. Depok : Geografi Fipia UI.

Sumaatmadja, N.1988. Geografi Pemba ngunan.Jakarta: Direktorat Pendidik an Tinggi. 